\title{
PERSPECTIVAS DA CONCORRÊNCIA NA ORDEM ECONÔMICA CONSTITUCIONAL
}

MENDONÇA, João Josué Walmor de ${ }^{1}$

Recebido em: 2009-07-12

Aprovado em: 2009-09-12

ISSUE DOI: $10.3738 / 1982.2278 .269$

RESUMO: A análise tem seu aporte inicial a mirar a Teoria da Concorrência na Ordem Econômica Constitucional, a demonstrar os caminhos sistêmicos capazes de neutralizar os abusos da concorrência. O caminho a trilhar será o esquema dogmático a seguir: arts. $1^{\circ}, \mathrm{IV}, 3^{\circ}$, $5^{\circ}$, caput, XIII, XXII, XXIII, XXXII, todos da CF/88, com as implicações na Lei n. 8.884, de 11 de junho de 1994. Claro, as influências dos outros diplomas legais serão pertinentes para legitimar os objetivos fundamentais e principiológicos responsáveis para atingir o fim destes, a resguardar o consumidor no plano da concorrência. Nestes termos, baliza-se o objeto entre os princípios fundamentais (Título I), os direitos e garantias fundamentais, nos direitos e deveres individuais e coletivos (Título II), da ordem econômica e financeira, nos princípios gerais da atividade econômica (Título VII), da $\mathrm{CF} / 88$, com as demais ramificações possíveis, a influenciar, incidir diretamente no âmbito da concorrência, Lei $\mathrm{n}^{\circ}$ 8.884/94. Aborda-se, de forma didática e conceitual, os fins tendentes a formar esta Ordem e, expor, de forma objetiva, possibilidades lógicas de esquemas dogmáticos para empreender uma segurança à tutela da concorrência, a visar o cidadão, o consumidor.

Palavras-chave: Teoria da Concorrência. Ordem Constitucional. Proteção do cidadão.

\section{PERSPECTIVE FOR ECONOMIC COMPETITION IN CONSTITUTIONAL ORDER}

\begin{abstract}
SUMMARY: The analysis has its initial contribution to the Theory of Competition in Constitutional Economic Order, to demonstrate the ways able to neutralize the systemic abuse of the competition. The path to demonstrate is the dogmatic plain: arts. 1, IV, 3, 5, caput, XIII, XXII, XXIII, XXXII, all of CF/88, with implications for the Law n. 8.884, 11 June 1994. The influences of other acts will be necessary to legitimize the fundamental objectives and responsible principle logic to reach the end, to protect the consumer in plain of competition. By the way, to mark the object is between the fundamental principles (Title I), the rights and guarantees, rights and duties in individual and collective (Title II), the economic and financial order, the general principles of economic activity (Title VII ) of $\mathrm{CF} / 88$ with the other possible (and necessary) ramifications, to influence directly address the competition, Law n. 8.884/94. The approach will be intuitive and conceptual, the purpose to make this Order, and expose, in an objective, logical possibilities of dogmatic to undertake a security for the protection of competition, to protection the citizen and the consumer.
\end{abstract}

Keywords: Theory of competition. Constitutional Order. Protection the citizen.

\footnotetext{
${ }^{1}$ Advogado. Inscrito na $70^{\text {a }}$ Subsecção da OABSP. Graduado pela Faculdade de Direito da Universidade de Franca - UNIFRAN. Texto redigido em abril-2006.
} 


\section{INTRODUÇÃO}

A análise tem seu aporte inicial a mirar a Teoria da Concorrência na Ordem Econômica Constitucional, a demonstrar os caminhos sistêmicos capazes de neutralizar os abusos da concorrência.

O caminho a trilhar será o esquema dogmático a seguir: arts. $1^{\circ}, \mathrm{IV}, 3^{\circ}, 5^{\circ}$, caput, XIII, XXII, XXIII, XXXII, todos da CF/88, com as implicações na Lei n. 8.884, de 11 de junho de 1994.

Claro, as influências dos outros diplomas legais serão pertinentes para legitimar os objetivos fundamentais e principiológicos responsáveis para atingir o fim destes, a resguardar o consumidor no plano da concorrência.

O objeto caminhará (tópica) entre os princípios fundamentais (Título I), os direitos e garantias fundamentais, nos direitos e deveres individuais e coletivos (Título II), da ordem econômica e financeira, nos princípios gerais da atividade econômica (Título VII), da CF/88, com as demais ramificações possíveis, a influenciar, incidir diretamente no âmbito da concorrência, Lei n ${ }^{\circ} 8.884 / 94$.

Desta forma, o apanhado dogmático será o vetor necessário e restrito deste estudo, a merecer guarida a concepção de que o direito é uma experiência normativa, baseado nas normas e por ela cambiado, sem que com isso, possa negar outras influências ou concepções jusfilosóficas. Antes de discutir as influências destas, necessita-se, nesta análise, explorar as possibilidades das densidades normativas no texto constitucional.

Aborda-se, de forma didática e conceitual, os fins tendentes a formar esta Ordem Constitucional e, expor, de forma objetiva, possibilidades lógicas de esquemas dogmáticos para empreender uma segurança à tutela da concorrência, a visar o cidadão, o consumidor.

\section{O VALOR SOCIAL DO TRABALHO}

A Constituição brasileira de 1946 foi a primeira a empregar expressamente a valorização do trabalho, na ordem econômica, conforme o art. 145: "[...] princípios da justiça social, conciliando a liberdade de iniciativa com a valorização do trabalho humano". Na Constituição de 1967 e na de 1969, que manteve aquela inalterada, trazia no bojo do art. 160, II, que a valorização do trabalho era condição da dignidade humana. 
No inciso IV do art. $1^{\circ}$ (Título I - dos princípios fundamentais) da CF/88, os valores sociais do trabalho é o escopo fundamental garantido pelo Estado na pretensa Ordem Econômica abstrata e programática, a preservar, sempre, os valores advindos do trabalho, não somente no e ao trabalhador, mas seu desenvolvimento na sociedade; a importância qualitativa que assume no desenvolvimento da sociedade, a impulsionar a construção de uma sociedade justa e solidária (art. $3^{\circ}, \mathrm{I}, \mathrm{CF} / 88$ ) é máxima e incontestável esta garantia, sendo forma fundamental do Estado Democrático de Direito.

Daí que uma noção fria e produtiva (apenas) do valor do trabalho não é aceita e, muito menos, seja algo supletivo (o que se pode retirar e continuar inalterado, como o mesmo significado e importância), pelo contrário, o valor do trabalho é fonte espiritual, moral, material para o trabalhador.

Por isto, o homem - leia-se empreendedor - precisa valorizar a parte humana do trabalho, não apenas a produção de riqueza material. E o que vem a ser produção de riqueza material? "O processo de produção de riqueza material abrange o trabalho humano, os meios de trabalho e os objetos do trabalho" (NIKITIN, 1967, p. 2). Deste modo, toda a sociedade se desenvolve, pois o trabalho movimenta a sociedade, faz com que ela evolua.

Assim, o que determina o desenvolvimento da sociedade? Nikitin (1967, p. 2) diz que Marx foi quem primeiro respondeu, com a seguinte imagem:

\footnotetext{
Para viver, os homens precisam de comida e roupa, casa e outros meios materiais de vida, e para tê-los devem produzi-los (sic), devem trabalhar. Toda a sociedade desmorona no momento em que deixa de produzir riqueza material. Por conseguinte, a produção de riqueza material é a base da vida e do desenvolvimento de qualquer sociedade.
}

O vetor força humana do trabalho, ou seja, a sua capacidade de produção, de produzir trabalho (produzir a mais valia), está voltado para satisfação da produção de riqueza material. É a parte útil para que esta se concretize. O homem adapta, transforma as coisas naturais às suas necessidades.

A incorporação do valor do trabalho no homem afasta a idéia de romper (superar) com o sistema capitalista ${ }^{2}$. Mesmo porque, a concepção de Marx da

\footnotetext{
${ }^{2}$ Esta conformação de não rompimento (superação) com o sistema vigente não é a admissão de tê-lo ou não como justo. Todo o sistema capitalista, ou todo o sistema de mercado, há lugares, fatores, barreiras deveras ser submetidas à (re)leitura para enquadrar (melhor) a (re)distribuição de renda, oportunidades (reais) de luta, de mercado aberto e satisfação do social, sem que, com isto, possa haver rompimento com o atual sistema. $\mathrm{O}$ importante salientar é que, de fato, pela abordagem sistemática, como se aborda, e não justa, o sistema funciona,
} 
sociedade era apenas a satisfação do homem na sua porção material, mas é nesta porção material (e não a única) que ele, o homem, o trabalhador se realiza. É imprescindível na vida moderna o modo de produção da vida material, como quer Marx, mas não é o bastante.

Silva Neto (2001, p. 144), salienta:

\begin{abstract}
Diferentemente do que acontecera sob os auspícios do Estado absenteísta liberal, a autoconferência de legitimidade ao ente estatal somente se dará se se mostrar capaz de sustentar a demanda coletiva por garantias sociais básicas, malgrado os paladinos do Estado mínimo porfiem por tornar verdade - e gastem milhões em publicidade para isso - que assuntos do tipo 'previdência', 'saúde', 'educação', e 'segurança' não representam prestações de cunho social de obrigação do Estado.
\end{abstract}

Os objetivos inseridos neste princípio - valores sociais do trabalho - têm desdobramentos nos direitos e deveres do indivíduo e do coletivo, mormente a positivação do art. $5^{\circ}$, XIII, CF/88, onde é livre o exercício de qualquer trabalho, ofício ou profissão, atendidas as qualificações profissionais que a lei estabelecer.

Deste modo, o parágrafo único do art. $170, \mathrm{CF} / 88$, que se insere nos princípios gerais da atividade econômica (Título IV), assegura: a todos o livre exercício de qualquer atividade econômica, como objetivo a seguir respaldado no princípio maior e norteador dos valores sociais do trabalho.

Desta forma, conjugando o inciso XIII, art. $5^{\circ}$ com parágrafo único, art. 170 , tem-se a proteção do trabalho, e da atividade. A CF/88 valoriza, protege, estabelece a plenitude do cidadão no seu desempenho, e também na atividade a desempenhar.

Também o art. 170, caput, $\mathrm{CF} / 88$, traz o princípio da valorização do trabalho humano como diretriz a ser observado, tanto que no inciso VII, pugna pela redução das desigualdades regionais e sociais, o que não se recomenda deixar de analisar com os elementos contidos e mencionados no Preâmbulo da Constituição - parte norteadora da ideologia que o constituinte originário determina à Constituição -, com o art. $3^{\circ}$ e, no plano constitucional internacional, o parágrafo único do art. $4^{\circ}$.

tem respostas rápidas e aptas a suprir incongruências entre busca-procura, seja no âmbito de mercado de investimento (especulativo) ou no setor de empregos. 


\section{LIVRE INICIATIVA}

A expressão livre iniciativa surge na Constituição de 1946 no art. 145: “A ordem econômica deve ser organizada conforme os princípios da justiça social, conciliando a liberdade de iniciativa com a valorização do trabalho humano". A Constituição de 1967 reproduziu tal expressão, em seu art. 157, I, e considerou-a como princípio da ordem econômica da época. A EC n. 1 de 69 também se referiu em iguais condições, no art. 160, I.

A doutrina da livre iniciativa no final do século $\mathrm{XX}$ influenciou $\mathrm{o}$ constituinte originário de 1988 e tratou-a como fundamento do Estado Democrático de Direito no art. $1^{\circ}$, IV. Assim, a livre iniciativa ocupa lugar de destaque na estrutura política inserindo-a no Título I - dos princípios fundamentais - da CF/88.

Como já visto, a livre iniciativa está positivada no caput do art. 170, ao lado da valorização do trabalho humano. Este "enquadramento dúplice, pela Constituição, da livre iniciativa acaba por enfatizar ainda mais a relevância do princípio do ordenamento constitucional brasileiro", como ressalta Tavares (2003, p. 247).

José Afonso da Silva (apud TAVARES, 2003, p. 247) diz que a Constituição consagra uma economia de mercado, de natureza capitalista, pois a iniciativa privada é o princípio norteador da ordem capitalista. O inciso I do art. $3^{\circ}, \mathrm{CF} / 88$, quando almeja construir uma sociedade livre, justa e solidária, também alude à iniciativa privada, a garantia das sociedades mercantis, a liberdade de associação (art. $5^{\circ}$, XVII usque XXI, CF/88), culminando no art. $8^{\circ}, \mathrm{CF} / 88$, dos direitos sociais.

Assim, a liberdade de iniciativa não tem uma conotação apenas econômica, há mais dimensões, como a citada, responsáveis também, além da parte financeira, econômica, a prestação social e o empreendedorismo.

Há a liberdade de desenvolvimento da empresa, da indústria, comércio ou contrato (o que se desdobra no corolário da garantia do direito de propriedade art. $5^{\circ}$, XXII e XXIII), assim, compreende algumas formas de organização econômica, individuais ou coletivas, v. g., cooperativa (art. $5^{\circ}$, XVIII; art. 174, $\S \S$ $3^{\circ}$ e $4^{\circ}$ ) mais a iniciativa pública (art. 173, 177 e 192, II).

Themistócles Brandão Cavalcanti (apud TAVARES, 2003, p. 248), diz: 
Liberdade de iniciativa considerada sob o aspecto da free enterprise dos americanos tem os seguintes característicos próprios: a) a apropriação privada, particular, da propriedade e dos bens de produção e consumo; b) a aceitação ética e econômica do princípio firmado de que essas empresas devem ser (sic) fins lucrativos; c) a admissão da concorrência como o melhor meio de obter maior eficácia nos negócios; d) a certeza de que o mínimo de intervenções nos negócios permite maiores oportunidades aos melhores.

Por demais que possa se afirmar, a livre iniciativa tem a idéia de dois sentidos, sendo um primeiro positivo e o segundo negativo. $\mathrm{Na}$ interpretação do parágrafo único como caput do art. 170, $\mathrm{CF} / 88$, quando o livre exercício de qualquer atividade é assegurado, independentemente de autorização de órgãos públicos, salvo nos casos previstos em lei e a existência digna, o livre exercício é feito conforme as atividades lícitas e dentro dos limites que a lei determina, esse exercício é a atividade segura, com respaldo legal, v. g., uma sociedade de fato, mesmo sem inscrição na Junta Comercial, como a maioria das cidades que possuem bares, botequins, lanchonetes.

Outro sentido é a intervenção estatal para limitar esta atividade empreendedora nociva que ultrapassa os limites da razoabilidade da livre concorrência, a lesar os interesses econômicos, v. $g$., a formação de cartéis, como os países membros produtores de petróleo - OPEP -, mesmo a OMC Organização Mundial do Comércio - quando não pune aquele grupo, nem por isso escapa de ferir a idéia de livre concorrência, detentora dos valores do caput do art. 170 .

Destarte as benfeitorias do sistema da livre iniciativa, as restrições referentes a este sistema, quando não corretamente ajustado, escapam os limites do razoável mais os fins sociais, para a não diminuição da desigualdade e lesa tanto o consumidor quanto o empreendedor.

No caso do empreendedor, pode se analisar de forma sistemática com a liberdade de contratar, a livre disponibilidade de sua propriedade (visão liberal), a envolver ou não nos negócios a criar e fomenta-los, como lastro nos contratos, toda esta garantia assegurada de forma programática, no plano constitucional, deve ser produzida pela legislação infraconstitucional, não para dar unidade formal ao sistema, mas para dar eficácia aos fins assim determinados.

Os contratos devem ser celebrados de tal maneira que impeça lesionar os interesses dos consumidores, não deve a livre iniciativa ter um planejamento vinculante, o empresário deve ser livre para determinar o que, como, quando 
produzir e qual o preço a vender, como ensina Bastos (apud TAVARES, 2003, p. 250).

Tal é o entendimento, mesmo no plano privado, que o art. 174, caput, $\mathrm{CF} / 88$, diz que "como agente normativo e regulador da atividade econômica, o Estado exercerá, na forma da lei, as funções de fiscalização, incentivo e planejamento, sendo este determinante para o setor público e indicativo para o setor privado".

Esta fiscalização, no plano da concorrência (liberdade de mercado, iniciativa, etc.), está determinada conforme a Lei n. 8.884 de 11 de junho de 1994 que transformou o Conselho Administrativo de Defesa Econômica - CADE em autarquia, e dispôs sobre a prevenção e a repressão às infrações contra a ordem econômica e deu outras providências.

No plano privado, o empresário goza de liberdade de contratar, de exercer suas atividades de empreendedor, mas deve estar em conformidade com o planejamento e o indicativo do poder regulador estatal. Não há que se dizer um intervencionismo do Estado na esfera privada, apenas o poder regulador, fiscalizador e normativo, ou seja, o próprio poder de polícia de atuação estatal.

No plano público, quando age como empresário o Estado, aqui sim, não goza de discricionariedade o ente público, devendo seguir, obrigatoriamente, as determinações legais, v.g., as licitações, concessões, permissões, contratos públicos, etc., ressalvados os casos emergenciais, calamidades e guerra. Todas estas determinações são diretrizes legais e bases de planejamento que vinculam o administrador público na gestão da coisa pública.

Do lado do empreendedor, as limitações ao poder de contratar, pactuar e negociar são defesos a quaisquer atos atentatórios à dignidade da pessoa humana, como a utilização do abuso do poder econômico.

Por este poder entende-se:

a soma de meios, de natureza econômica, que habilita o agente a agir no mercado em que atua. Todo agente que atua no mercado - pessoa jurídica ou pessoa física - exerce - usa - o poder econômico de que dispõe; daí a expressão corrente, consagrada no direito norte-americano e recebida pelo direito brasileiro, poder econômico de mercado (economic market power). O uso do poder econômico - do, porque necessariamente identificado ao seu titular, que o exerce ou pode exerce-lo - não é apenas legítimo, senão indispensável à subsistência competitiva de seu detentor, pois é pelo exercício do seu poder que ele buscará a preferência de quem procura bens e serviços, que oferta, no mercado em que atua (DUTRA, 2003, p. 272-3). 
Mas, deve-se analisar tal fato isoladamente e longe de abusos. A legitimidade para utilizar-se do poder que detém é limitado: atua o agente para conquistar seu espaço no mercado, o que deve ser feito de forma que não lese os interesses sociais e os consumidores. A livre concorrência é a utilização deste poder econômico, propriamente dito, uma vez que o seu poder vai, com toda a certeza, garantir a empresa no mercado - interesse imediato, pelo lado empresarial - e, posteriormente, pautar pelo respeito ao consumidor - o interesse imediato, a dignidade da pessoa humana.

Contudo, o princípio da livre iniciativa pode ser sistematizado com o conteúdo do inciso II do art. $5^{\circ}$ da $\mathrm{CF} / 88$, quando "ninguém será obrigado a fazer ou deixar de fazer alguma coisa senão em virtude de lei", e como adverte Silva Neto (2001, p. 96): "o que nos leva a considerar que a liberdade de atuação na economia é apenas uma das porções da garantia fundamental, porquanto pode reconduzir, inclusive, à escolha de uma profissão pelo trabalhador”.

\section{LIVRE CONCORRÊNCIA}

Uma questão de controle semântico é dizer “o que é concorrência?” e, sem, contudo deixar de lado "livre". Concorrer é correr junto, disputar a preferência de quem está a procura de algo - bem ou serviço - ofertado no mercado. O que deve ser livre é do abuso advindo do poder econômico, como bem ressalta Dutra (2003, p. 279). É o que vem a ser "abuso?", ele pode ser enquadrado quando houver poder econômico, ou seja, é o excesso da utilização do poder econômico, "não pode haver abuso quando não haja poder econômico". (BRUNA 2001, p. 128-9):

\footnotetext{
Isto porque já houve, neste país, invocação do princípio de repressão ao abuso do poder econômico para justificar congelamento geral de preços e mesmo para o controle dos mesmos, com vistas à redução da inflação. Isso certamente não teria ocorrido fosse mais disseminada, nos meios jurídicos, a afirmação óbvia de que só pode haver abuso quando houver poder econômico.
}

O princípio da livre concorrência ${ }^{3}$, contido no inciso IV do art. 170 da $\mathrm{CF} / 88$, é princípio erigido pelo constituinte originário, que não deve ser interpretado longe e desvinculado do princípio da livre iniciativa, pois estão ligados entre si, de tal forma que é impossível tratá-los de forma isolada.

${ }^{3}$ Canotilho (apud GRAU, 2003, p. 180), diz ser um princípio constitucional impositivo. 
Também, a seguir, no art. 173, $\S 4^{\circ}$, diz que “a lei reprimirá o abuso do poder econômico que vise à dominação dos mercados, à eliminação da concorrência e ao aumento arbitrário de lucros" (sendo esta lei, a Lei n. 8.884/94)

A CF/88 erige à livre iniciativa, inciso IV do art. $1^{\circ}$, como fundamento do próprio Estado Democrático de Direito, pode-se dizer, no plano político e no plano econômico, e procura dar maior eficácia quando positiva a livre concorrência como princípio da Ordem Econômica e Financeira, como se percebe no caput do art. 170.

O sistema capitalista, adotado na Ordem Econômica brasileira, tem uma conseqüência lógica é a livre concorrência proteger a livre iniciativa (que tem cunho liberal, privatista e garantidor do direito à propriedade), que contribui para a própria manutenção do capitalismo. Importante ressaltar que o sistema adotado tem como corolário principal, a ampla garantia que se destina "a assegurar o exercício dos direitos sociais e individuais, a liberdade, a segurança, o bem-estar, o desenvolvimento [...]", como se entende do Preâmbulo da CF/88. Portanto, este princípio é destinado à sociedade e não à empresa, como diz Grau (2003, p. 194).

Celso Ribeiro Bastos (apud TAVARES, 2003, p. 254), frisa que "só pode existir a livre concorrência onde há livre iniciativa. O inverso, no entanto, não é verdadeiro - pode existir livre iniciativa sem livre concorrência. Assim, a livre concorrência é algo que se agrega à livre iniciativa".

Para uma definição de livre concorrência, Tavares (2003, p. 255) diz que é “[...] a abertura jurídica concedida aos particulares para competirem entre si, em segmento lícito, objetivando o êxito econômico pelas leis de mercado". Ainda, este autor cita Celso Ribeiro Bastos: "a existência de diversos produtores ou prestadores de serviço" e "consiste na situação em que se encontram os diversos agentes produtores de estarem dispostos à concorrência dos seus rivais". Também cita Carlo Barbieri Filho, "concorrência é disputar, em condições de igualdade, cada espaço com objetivos lícitos, compatíveis com as aspirações nacionais. Consiste, no setor econômico, na disputa entre todas as empresas para conseguir maior e melhor espaço no mercado."

A importância da livre concorrência é fundamental no contexto da economia de mercado, e noutra perspectiva, na proteção ao consumidor.

Quando a livre concorrência tem a competição sadia, exige que o empresário se empenhe à promoção e à possibilidade na melhoria, na qualidade e na variedade dos produtos, bens, serviços, ainda a proporcionar o equilíbrio de 
mercado - oferta-procura -, a favorecer condições para preços acessíveis ao consumidor, portanto, tais fatores só favorecem e determinam equilíbrios nas relações.

Bastos (2001, p. 471) diz que a livre concorrência é basilar da estrutura liberal,

\begin{abstract}
Porque é pelo seu jogo, pelo seu funcionamento, que os consumidores vêem assegurados os seus direitos a consumir produtos de qualidade e preços justos. E, de outra parte, para quem se lança à atividade econômica, é uma forma de obter a recompensa pela sua maior capacidade, pela sua maior dedicação, pelo seu empenho maior, prosperando, consequentemente, mais do que seus concorrentes.
\end{abstract}

A busca pela concorrência possível, no mundo capitalista e devorador de hoje, impõe ao empreendedor, para utilizar-se de seus benefícios, o investimento em tecnologia e pesquisa, principalmente, a pesquisa de mercado, pois o empreendedor busca lucros, confiabilidade do consumidor e a estabilidade no mercado, enquanto o consumidor busca melhores produtos, melhores preços, confiabilidade do produto, serviço, bens disponíveis no mercado, e quando expostos de maneira correta e oferecidos em conformidade com seus desejos, expectativas, ganha o empreendedor, o consumidor, o mercado, interno e externo.

Muitas empresas buscam a melhora da qualidade de seus produtos investindo em setores que, aparentemente não tem conotação de melhoria direta com o produto, mas tem sido o diferencial quando da escolha do consumidor, que é a propaganda e o valor agregado da marca do produto, ou seja, a confiabilidade da sua marca no mercado, como dito.

Em termos de mercado interno, a concorrência saudável tem proporcionado uma busca pela melhora nos produtos mais a elevação da qualidade potencial desse mercado, tanto que os desdobramentos úteis são: a consolidação da estrutura forte e confiável, no plano mercadológico externo, com a aceitação do consumidor, seja nacional, seja o internacional.

Com a globalização do mercado e do social, o mundo tende a diminuir-se geograficamente (e porquê não temporalmente?), principalmente com as tecnologias de rede - internet -, onde as networks são cada vez mais seletas. Portanto, a concorrência praticada de forma idônea, saudável, tende a despertar os investimentos externos, buscando a integração econômica e social (parágrafo único, art. $\left.4^{\circ}, \mathrm{CF} / 88\right)$, ao passo que, como prevê o art. $3^{\circ}$, garante o 
desenvolvimento nacional (II), calibra a vontade de erradicar a pobreza, marginalização e reduz as desigualdades sociais (IV).

Neste passo, a concorrência tem sido estritamente seletiva, como dito, os produtos são encaminhados para grupos distintos da sociedade, adequando às diferenças, expectativas e buscando a atender as peculiaridades de cada cidadão, sem ferir as suas diferenças - art. $5^{\circ}$, caput, todos são iguais, sem distinção de qualquer natureza -, a promover o bem de todos, sem preconceitos de origem, raça, sexo, cor, idade e quaisquer outras formas de discriminação (IV do art. $3^{\circ}$ ).

Por outro lado, tem-se a utilização da livre concorrência para caracterizar o abuso do poder econômico, o que proporcionará a intervenção do Estado para (re)estabelecer o equilíbrio do mercado e a proteção ao consumidor.

O que se diz do caput do art. 173 da CF/88, o Estado agirá com o poder de polícia, como regulador e fiscalizador das atividades relevantes ao interesse coletivo, com isto, o legislador ordinário outorgou competência ao Conselho Administrativo de Defesa Econômica - CADE - delimitando o seu campo de atuação, com aplicação da Lei n. 8.884/94, art. 15: “às pessoas físicas ou jurídicas de direito público ou privado, bem como a quaisquer associações de entidades ou pessoas, constituídas de fato ou de direito, ainda que temporariamente, com ou sem personalidade jurídica, mesmo que exerçam atividade sob regime de monopólio legal."

No $\S 4^{\circ}$, art. $173, \mathrm{CF} / 88$, está positivado que "a lei reprimirá o abuso do poder econômico que vise à dominação dos mercados, à eliminação da concorrência e ao aumento arbitrário dos lucros." Portanto, toda a atuação, conduta, dos agentes econômicos presente no mercado ou atuam com bens, ou serviços, está sob a égide da Lei n. 8.884/94, responsável pela eficácia do princípio constitucional da livre concorrência.

A Lei n. 8.884/94 é responsável pela prevenção, repressão às infrações contra a ordem econômica, no seu art. $1^{\circ}$ diz: “[...] infrações contra a ordem econômica, orientada pelos ditames constitucionais de liberdade de iniciativa, livre concorrência, função social da propriedade, defesa dos consumidores e repressão ao abuso do poder econômico."

Assim, tem-se a necessidade de extirpar o abuso do poder econômico, pois é contra todos os valores fundamentais do Estado Democrático de Direito, contra os princípios da Ordem Econômica e o valor fundamental de todo o Estado e a 
Ordem Econômica: que é o cidadão (no plano político), o consumidor (no plano econômico).

É próprio do sistema capitalista, promover o equilíbrio de mercado e não a exploração do homem pelo homem ${ }^{4}$ que também mereceu guarida constitucional, inciso XIII do art. $5^{\circ}, 6^{\circ}$ e $7^{\circ}$. Por isto a CF/88 elevou a defesa do consumidor como preceito fundamental, inciso XXXII do art. 5 (também as Leis n. 8.884 /94, 8.078/90 - Código de Defesa do Consumidor) e também a defesa da propriedade, incisos XXII e XXIII do art. $5^{\circ}$.

\title{
4 DA DEFESA DO CONSUMIDOR
}

A tutela do consumidor é outro princípio da Ordem Econômica Constitucional positivado no art. 170, V da CF/88. Como relata Grau (2003, p. 216):

\begin{abstract}
Princípio constitucional impositivo (Canotilho), a cumprir dupla função, como instrumento para a realização do fim de assegurar a todos existência digna e objetivo particular a ser alcançado. No último sentido, assume a feição de diretriz (Dworkin) - norma-objetivo dotada de caráter constitucional conformador, justificando a reivindicação pela realização de políticas públicas.
\end{abstract}

Na retrospectiva legislativa, o Dec. Lei n. 7.666, de 22 de junho de 1945 que dispunha sobre atos contrários à ordem moral e econômica, já no seu art. $1^{\circ}$, I, "a", dizia "elevar o preço de venda dos respectivos produtos". Este decreto foi revogado pelo Dec. Lei n. 8.167, de 9 de novembro de 1945.

$\mathrm{Na}$ tradição constitucional, pode notar a Carta Política de 1946, art. 148 que "a lei reprimirá toda e qualquer forma de abuso do poder econômico, inclusive as uniões ou agrupamentos de empresas individuais ou sociais, seja qual for a sua natureza, que tenham por fim dominar os mercados nacionais, eliminar a concorrência e aumentar arbitrariamente os lucros," já na Constituição Federal de 1967, art. 160 - A lei disporá sobre o regime das empresas concessionárias de serviços públicos federais, estaduais e municipais, estabelecendo: IV - repressão ao abuso do poder econômico, caracterizado pelo domínio dos mercados, a eliminação da concorrência e o aumento arbitrário dos lucros. $\mathrm{Na} \mathrm{CF} / 88$,

${ }^{4}$ Cf.: SILVA NETO (2001, p. 142), no tocante à exploração do homem pelo homem, o autor ressalta a importância do pensamento de Max Weber sobre a relação do Estado como violência legítima, assim, o autor cita a obra de Weber, Ciência e Política: "o Estado consiste em uma relação de dominação do homem sobre o homem, fundada no instrumento da violência legítima (isto é, da violência considerada legítima). O Estado só pode existir, portanto, sob condição de que os homens dominados se submetem à autoridade continuamente reivindicada pelos dominadores". 
encontra-se no art. $173, \S 4^{\circ}$, “a lei reprimirá o abuso do poder econômico que vise à dominação dos mercados, à eliminação da concorrência e ao aumento arbitrário dos lucros".

Desta forma, o consumidor se consagra, como disposto no inciso XXXII do art. $5^{\circ}$ da CF/88, como direito constitucional fundamental. Também, pode ser feito o seguinte rol da legislação, simplificadamente: art. 24 , VIII, $150, \S 5^{\circ}, 173, \S \S 3^{\circ}$ e $4^{\circ}, 175$, parágrafo único, II e IV, CF/88; Lei n. 8.884/94, prevenção e repressão às infrações contra a ordem econômica - CADE; Lei n. 8.078/90, dispõe sobre a proteção do consumidor - Código de Defesa do Consumidor; Dec. Lei n. 2.181/97, dispõe sobre a organização do Sistema Nacional de Defesa do Consumidor - SNDC, e também estabelece normas gerais de aplicação das sanções administrativas previstas na Lei n. 8.884/94; Lei n. 8.137/90, que define os crimes contra a ordem econômica, tributária e contra as relações de consumo. Voltaremos às questões legislativas adiante, antes, fixemos alguns pontos.

A idéia fundamental que se deve ter deste princípio constitucional é que o sistema de mercado justifica-se pela sua capacidade de produzir mais e melhor os bens de consumo, o que significa ter eficiência alocatícia e a idéia de distribuição da riqueza, que é a eficiência distributiva, como diz Lopes (2000, p. 79).

O direito do consumidor é diferente do direito da concorrência, pois este tem a função de organizar o mercado e aquele visa a preservação do interesses particulares de sujeitos privados, como diz Meledo-Briand (2002, p. 39), “[...] no contrato celebrado, é reconhecido, ou até mesmo presumido um desequilíbrio, uma desigualdade".

Não obstante estas considerações preliminares são necessárias pontuar algumas questões. O que vem a ser consumidor? A Lei n. 8.078, de 11 de setembro de 1990, que dispõe sobre a proteção do consumidor e dá outras providências, no seu art. $2^{\circ}$, diz que "consumidor é toda pessoa física ou jurídica que adquire ou utiliza produto ou serviço como destinatário final." O destino próprio, final, com a finalidade de satisfação da pessoa que, por qualquer modo, tem em seu poder, produto, serviço ou utiliza-se deles, é potencialmente o consumidor, quem se relaciona como ele - produto, serviço - é equiparado ao consumidor, por força do parágrafo único deste artigo em comento.

Por outro lado, figura o fornecedor, que o art. $3^{\circ}$ da mesma lei define como “[...] toda pessoa física ou jurídica, pública ou privada, nacional ou estrangeira, bem como os entes despersonalizados, que desenvolvem atividades de produção, 
montagem, criação, construção, transformação, importação, exportação, distribuição ou comercialização de produtos ou prestação de serviços," é o fornecedor. Este artigo trás o conceito de produto $-\S 1^{\circ}$ : “[...] qualquer bem, móvel ou imóvel, material ou imaterial" - e de serviço - § 2: “[...] qualquer atividade fornecida no mercado de consumo, mediante remuneração, inclusive as de natureza bancária, financeira ${ }^{5}$, de crédito e securitária ${ }^{6}$, salvo as decorrentes das relações de caráter trabalhista.'

A Lei n. 8.884/94, no seu art. $1^{\circ}$, caput, erige a defesa dos consumidores como finalidade, e no art. 20, quando diz da constituição da infração da ordem econômica, o inciso III diz "aumentar arbitrariamente os lucros", o destinatário desta norma, o que se parece, é o consumidor. Forgioni (1998, p. 235) também orienta neste sentido do destino ao consumidor, “[...] se a repressão ao lucro arbitrário não vai ao encontro dos interesses do mercado, seria mesmo fechar-se em uma teórica torre de marfim não admitirmos que essa repressão visa, precipuamente, à proteção do consumidor". No entanto, os incisos I, II e IV, se destinam a proteger o mercado e os empreendedores de forma indireta, e o consumidor de forma direta porque antes tem o inciso III que inibe o aumento injustificado dos lucros, corolário da livre iniciativa e da livre concorrência (FORGIONI, 1998, p. 239).

Alhures se encontram normas destinadas à proteção do consumidor com a repressão ao abuso do poder econômico e o aumento injustificado dos lucros, como às normas contidas na Lei n. 4.137/62. Sobre este diploma legal, Nelson de Azevedo Branco e Celso de Albuquerque Barreto (apud FORGIONI, 1998, p. 236), relatam que:

A legislação brasileira antitruste, embora impregnada de um sentido neoliberalista, não tem como único objetivo restabelecer o livre mecanismo de preços e da concorrência. O legislador constituinte procurou, ainda, proteger o consumidor contra a sede de lucros excessivos por parte de empresas ou associações de produtos que pretendam aumentar, arbitrariamente, seus ganhos em função de posições monopolísticas.

\footnotetext{
${ }^{5}$ Tem manifestado o STJ que às instituições financeiras devem aplicar o Código de Defesa do Consumidor, Súm. n. 297 do STJ.

${ }^{6}$ Também, sobre a aplicação do CDC, Súm. n. 321 do STJ, com o seguinte dizer: "O Código de Defesa do Consumidor é aplicável à relação jurídica entre a entidade de previdência privada e seus participantes".
} 
O inciso III do art. 20, da Lei do CADE, quando examinado com o inciso III do art. $4^{\circ}$ do CDC que estabelece a "harmonização dos interesses dos participantes das relações de consumo e compatibilização da proteção do consumidor com a necessidade de desenvolvimento econômico e tecnológico, de modo a viabilizar os princípios nos quais se funda a ordem econômica (art. 170 da Constituição Federal), sempre com base na boa-fé e equilíbrio nas relações entre consumidores e fornecedores", a política nacional de relações de consumo e a prevenção e a repressão às infrações contra a Ordem Econômica, visa o consumidor em primeiro lugar e refuta as práticas lesivas a este, com as circunstâncias previstas no rol do art. 21 da Lei do CADE.

Como se nota dos incisos I - "fixar ou praticar, em acordo com concorrente, sob qualquer forma, preços e condições de venda de bens ou de prestação de serviços” - e II - “obter ou influenciar a adoção de conduta comercial uniforme ou concertada entre concorrente" -, do art. 21, configuram hipóteses previstas no art. 20, principalmente da perspectiva do inciso III, quando o consumidor se realiza como finalidade protetiva destes diplomas legais infraconstitucionais.

No desdobramento do inciso III do art. 20, todas as questões referentes às variações de preços, seja direta ou indiretamente, que afetarem o consumidor, devem ser analisadas e sistematizadas, como se afere dos demais incisos do art. 21, tais como, além dos já ditos, especialmente os incisos I, II e IV do parágrafo único, quando dispõe das condições caracterizadoras do aumento excessivo ou injustificado dos preços.

Ainda, não passa despercebido dos outros dispositivos legais, tanto que no CDC, das práticas abusivas, art. 39, X, é defeso "elevar sem justa causa o preço de produtos ou serviços"; na Lei 8.137/90, com redação do art. 85 da Lei n. 8.884/94 que determinou nova redação ao inciso VII do art. $4^{\circ}$, dispõe que "elevar sem justa causa o preço de bem ou serviço, valendo-se de posição dominante no mercado", constitui crime contra a Ordem Econômica.

As variações de preços, os conluios de empresas, devem ser fortemente combatidos, pois a forma de monopólio natural, conquista global e justa do mercado, quando fundado em processo natural de eficiência do agente econômico não tem o condão de dominar o mercado, mas é prática idônea e, sem sombra de dúvidas, acaba por ratificar, substancialmente, a livre concorrência, a livre 
iniciativa, valorizando o consumidor e estendendo credibilidade ao mercado atuante do agente econômico.

Com espeque em San Tiago Dantas (apud FORGIONI, 1998, p. 237), professa que:

Todas as vezes que se configura, na economia de um país, uma situação de monopólio natural, a intervenção econômica é inevitável para que a função reguladora dos preços e fornecimentos, entre pela ação dos fatores naturais e circunstanciais ao grupo dos monopolistas, não seja exercida em proveito exclusivo desse grupo, com prejuízo aos consumidores e da sociedade em geral.

Deste modo, a prática de processo natural pela busca de dominar o mercado, quando não afeta restritamente um grupo monopolista, é fator benéfico para desenvolver, estimular, fomentar o investimento em determinado setor. Mas, quando praticado em detrimentos de grupos, mesmo em monopólio natural, é fator de repulsa e implica em infração da ordem econômica, como visto no art. 20, Lei n. 8.884/94, prejudica a livre concorrência, a livre iniciativa, a caracterizar o uso e gozo abusivo de posição dominante no mercado, a constituir crime contra a ordem econômica, art. $4^{\circ}$ da Lei n. 8.137/90 e $\S 4^{\circ}$ do art. 173 da CF/88.

\section{DA PROPRIEDADE}

A propriedade é, em todos os tempos da História, o instituto mais polêmico. Importante salientar, oportunamente, a concepção do termo propriedade, vocábulo latino proprietas, que é qualidade do que é próprio (TAVARES, 2003, p. 156). Sobre o conceito do que vem a ser propriedade, Gilmar Ferreira Mendes (apud TOLEDO, 2004, p. 187-8), diz que é importante saber que este conceito constitucional não pode ser fixo, estático, mas sim dinâmico, relativo, “[...] afigurando-se, fundamentalmente, legítimas não só as novas definições de conteúdo, como a fixação de limites destinados a garantir sua função social. É que, embora, não aberto, o conceito constitucional de propriedade há de ser necessariamente dinâmico." Ou seja, deve-se lê-lo no plano relativo, fixado nos parâmetros da legislação ordinária. E, atender, fundamentalmente, o princípio da proporcionalidade.

Léon Duguit (apud TAVARES, 2003, p. 158), a propriedade passa da esfera puramente do direito subjetivo individual para a "[...] função social do detentor de capitais mobiliários e imobiliários", assim, 


\begin{abstract}
A propriedade implica para todo detentor de uma riqueza, a obrigação de empregá-la em acrescer a riqueza social, e, mercê dela, a interdependência social. Só ele pode cumprir certo dever social. Só ele pode aumentar a riqueza geral, fazendo valer a que ele detém. Se faz, pois, socialmente obrigado a cumprir aquele dever, a realizar a tarefa que a ele incumbe em relação aos bens que detenha, e não pode ser socialmente protegido se não a cumpre, e só na medida em que a cumpre.
\end{abstract}

Este pensamento está ligado à destinação que se dá à propriedade, a caracterizar a função social da propriedade, fator que se preocupa com a questão social e a justiça distributiva. Como se nota do pensamento de Duguit, a concepção de propriedade é a que serve a comunidade e não os anseios exclusivos do proprietário, necessitando buscar o bem estar de todos. Assim, a Carta Política de 1967, no seu art. 147, estabelecia que "o uso da propriedade será condicionado ao bem-estar social. A lei poderá, com observância do disposto no art. 141, § 16, promover a justa distribuição da propriedade, com igual oportunidade para todos".

Esta distribuição da propriedade tem cunho limitador, tanto para o proprietário e para o Estado, pois pode ser objeto de desapropriação, para satisfação, bem estar e fomento da ordem pública, atendida função social, bem como conciliar as múltiplas liberdades estabelecidas no texto constitucional, v. $g$, o direito de exclusivo, inciso XXVII, art. $5^{\circ}, \mathrm{CF} / 88$, em obras culturais de relevante valor social, cultural, pode ser mitigado, expropriado pela pessoa jurídica de direito público, quando o interesse público assim o exigir, como tem manifesto no aresto do STJ, REsp. 123.067/SP, n 1997/0017288-07.

Para garantir a propriedade no mundo moderno (ou para garantir o mundo moderno), sociedade de capital, a CF/88 erige como direito e garantia

${ }^{7}$ Cf.: Ementa: DIREITO AUTORAL. ESPETACULO REALIZADO NA RUA, COM SUBVENÇÃO DA PREFEITURA MUNICIPAL, INTEIRAMENTE GRATUITO, EM BENEFICIO DA COMUNIDADE. 1. NA LINHA DOS PRECEDENTES DA CORTE, O PAGAMENTO DOS DIREITOS AUTORAIS CABE QUANDO HOUVER QUALQUER TIPO DE PROVEITO, O QUE NÃO OCORRE NAQUELES CASOS NOS QUAIS NÃO HA COBRANÇA DE INGRESSO, NÃO HÁ PAGAMENTO AOS ARTISTAS, O ESPETACULO E REALIZADO NAS RUAS E A PARTICIPAÇÃO DO ENTE MUNICIPAL LIMITA-SE A UMA DETERMINADA SUBVENÇÃO AS ESCOLAS DE SAMBA QUE, EFETIVAMENTE RESPONDEM PELO ESPETACULO. TRATA-SE, NESTE CASO, DA PARTICIPAÇÃO GOVERNAMENTAL EM PROGRAMA DE DESENVOLVIMENTO DA CULTURA POPULAR EM EXCLUSIVO PROVEITO DA COMUNIDADE. 2. RECURSO ESPECIAL CONHECIDO, MAS IMPROVIDO.

Acórdão POR UNANIMIDADE, CONHECER DO RECURSO ESPECIAL, MAS NEGAR-LHE PROVIMENTO. (sic - como retirado da fonte). Relator Ministro Carlos Alberto Menezes Direito, da Terceira Turma, REsp 123067 / SP, no 1997/0017288-0, data do julgamento, 03/03/1998, data da publicação/fonte: DJ 18.05.1998 p. 83 e RSTJ vol. 110 p. 237. Fonte, disponível em: http://www.stj.gov.br/SCON/jurispru dencia/toc.jsp?livre=(('RESP'clap.+ou+'RESP'.clas. $)+e+@$ num='246908' $)+o u+\left({ }^{\prime} R E S P '+a d j+' 246\right.$ 908'.suce.), acesso: 03.04.06. 
fundamental o direito de propriedade (XXII, art. $5^{\circ}$ ) e a sua função social (XXIII, $\left.\operatorname{art.} 5^{\circ}\right)$.

No âmbito da ordem econômica, o art. 170, II e III, consagra de igual teor os princípios individuais, agora no âmbito da atividade econômica. Conclusão: ao enunciar a propriedade como garantia assegurada pela norma constitucional, concomitantemente, alude e revela o tipo de modelo econômico, que é o capitalista (SILVA NETO, 2001, p. 107).

Também há outras normas constitucionais que se referem ao direito de propriedade: arts. 5 incisos XXIV a XXX, 176, 177, 178, 182 a 186, 191 e 222. No plano infraconstitucional, cita-se o Código Civil de 2002, art. 1.228 a 1.368.

Desta forma, o constituinte, sob orientação capitalista, o princípio da propriedade privada, especialmente dos bens de produção, fundamento primordial do capitalismo como dito, sistematizado e interpretado pelos ditames do inciso IV do art. 170, CF/88, aliado à função social da propriedade (inciso II, art. 170 e inciso XXIII, art. $5^{\circ}$ ) se aplica à propriedade dos bens de produção.

O capitalismo se funda, entre outros fatores, na propriedade dos bens de produção, e o princípio da propriedade privada se radica no princípio próprio da liberdade, fundamento da democracia, como quer Toledo (2004, p. 187) e, “[...] por conseqüência, do próprio estado democrático de direito em que se constitui a República Federativa do Brasil".

Neste desenrolar, analisa-se agora, o esquema dogmático proposto por Sztajnberg (2004, p. 369, v. 2), onde a propriedade intelectual assume relevo importante em uma perspectiva concorrencial.

Estriba-se a autora na CF/88, art. $5^{\circ}$, XXIX, Lei n. 9.279/96, que dispõe sobre direitos e obrigações relativos à propriedade industrial (Lei de Propriedade Industrial - LPI), Lei n. 8.884/94, art. 24, Lei n. 8.078/90, art. 4º, VI.

O inciso XXIX, art. 5', CF/88 diz que "a lei assegurará aos autores de inventos industriais privilégio temporário para sua utilização, bem como proteção às criações industriais, à propriedade das marcas, aos nomes de empresas e a outros signos distintivos, tendo em vista o interesse social e o desenvolvimento tecnológico e econômico do pais".

Sobre o interesse social e desenvolvimento tecnológico e econômico do país, está gravado no caput do art. $2^{\circ}$ da LPI, e os meios para sua efetivação, os seus incisos. O privilégio temporário, ou seja, a patente propriamente dita, está positivado no caput do art. $6^{\circ}$, "ao autor de invenção ou modelo de utilidade será 
assegurado o direito de obter a patente que lhe garanta a propriedade [...]", e às patentes se consideram bens móveis (art. $5^{\circ}, \mathrm{LPI}$ ).

Nestes termos, enfoca-se a utilização segundo o interesse público e o desenvolvimento social, tecnológico, a mirar as penalidades advindas destes interesses quando descumprido pelo monopólio legal das patentes.

Importante ressaltar, a LPI é lei posterior e especial em relação à Lei do CADE, portanto, o disposto no art. 195 da LPI, que regula os crimes de concorrência desleal, tem aplicação primitiva, enquanto os arts. 21 e 24 da Lei do CADE têm aplicação subsidiária.

Assim, Sztajnberg (2004, p. 369, v. 2) considera a quebra do monopólio legal conferido pelas patentes, a dizer que este monopólio não é absoluto, onde o legislador ordinário cria a instituição da licença compulsória, art. 68 da LPI, que diz "o titular ficará sujeito a ter a patente licenciada compulsoriamente se exercer os direito dela decorrentes de forma abusiva, ou por meio dela praticar abuso de poder econômico, comprovado nos termos da lei, por decisão administrativa ou judicial" (sic - grifo nosso), e, o art. 24, IV, “a” da Lei do CADE recomenda aos órgãos públicos competentes que "seja concedida licença compulsória de patentes de titularidade do infrator" na hipótese de abuso do poder econômico $\left(\S 3^{\circ}\right.$, art. 68, LPI) contido nos incisos do art. 195 da LPI e caracterizado pelo art. 21, XVI, Lei do CADE.

Destarte, para entender o instituto da licença compulsória, importante entender o mecanismo para que se conceda o registro de patente. João Marcos Silveira (apud SZTAJNBERG, 2004, p. 369, v. 2), diz

Com o sistema de patente, o Estado incentiva o desenvolvimento e a divulgação de inovações técnicas ou tecnológicas de utilidade e aplicação industrial mediante a outorga, em contrapartida, de direitos exclusivos de exploração das invenções por um determinado período de tempo.

Deferido o pedido de patente, seu detentor possui o dito direito de exclusivo, o seu direito legítimo de impedir que outros utilizem dela sem autorização e eventual remuneração, os chamados royalties. Esse mecanismo é útil para coibir a utilização não autorizada, nocivo, ou com abuso de poder econômico através de patentes concedidas diz Sztajnberg (2004, p. 369, v. 2), como prevê o art. 68, as patentes licenciadas compulsoriamente. 


\section{CONCLUSÃO}

Desta forma, percebe-se que a teoria da concorrência na Ordem Econômica na Constituição, tem suas diretrizes e norte para os diversos diplomas legais mencionados no esquema proposto.

O que ficou caracterizado é a gama de princípios e importância que o legislador constituinte originário os erigiu como fundamento, do próprio Estado Democrático de Direito, da Ordem Econômica e Financeira e, obrigatoriamente, como Direitos Individuais Fundamentais.

A necessidade de proteger o consumidor e o mercado, e o próprio empreendedor são interesses a ser perseguidos por todos e, o primeiro, deve ser o norte e indicador para todos os agentes econômicos que atuam no mercado, seja no âmbito público ou no privado, pois é ele, o consumidor, fator determinante dos aspectos direcionais que o empreendedor deve seguir para manipular seus bens e produtos.

Espera-se, com este esboço, uma proveitosa (re)leitura e um caminho a trilhar por todos, na perspectiva da concorrência, com espeque de garantir e tutelar o cidadão, o consumidor.

\section{REFERÊNCIAS}

BARBIERI FILHO, C. Disciplina jurídica da concorrência: abuso do poder econômico. São Paulo: Resenha Tributária, 1984.

BASTOS, C. R. Curso de direito constitucional. 22. ed. São Paulo: Saraiva, 2001.

BRUNA, S. V. O poder econômico e a conceituação do abuso em seu exercício. São Paulo: Revista dos Tribunais, 2001.

DUTRA, P. Livre concorrência e regulação de mercados: estudos e pareceres. Rio de Janeiro: Renovar, 2003.

FARIAS, S. J. L. de. Evolução histórica dos princípios econômicos na constituição. p. 89-131. In: In: MARSHALL, C. C.; GOMES, J. M. M. (Coord.). Direito empresarial público. Rio de Janeiro: Lumen Júris, 2002. v. 2. 
FORGIONI, P. A. Os fundamentos do antitruste. São Paulo: Revista dos Tribunais, 1998.

GOMES, C. J. V. Ordem econômica constitucional e direito antitruste. Porto Alegre: Sergio Antonio Fabris Editor, 2004.

GRAU, E. R. A ordem econômica na constituição de 1988. 8. ed. São Paulo: Malheiros, 2003.

LOPES, J. R. de Lima. Direito da concorrência e direito do consumidor. In: Instituto Brasileiro de Direito do Consumidor. Revista de Direito do Consumidor. São Paulo: Revista dos Tribunais, ano 9, n. 34, abr-jun. de 2000.

MELEDO-BRIAND, D. A consideração dos interesses do consumidor e o direito da concorrência. In: Instituto Brasileiro de Direito do Consumidor. Revista de Direito do Consumidor. São Paulo: Revista dos Tribunais, ano 11, n. 44, out-dez. de 2002.

NIKITIN, P. Fundamentos de economia política. Tradução de A. Veiga Fialho. Rio de Janeiro: Civilização Brasileira, 1967.

SALOMÃO FILHO, C. Direito concorrencial: as condutas. São Paulo: Malheiros, 2003.

SILVA NETO, M. J. e. Direito constitucional econômico. São Paulo: LTR, 2001.

SOARES, J. C. T. Crimes contra a propriedade industrial e de concorrência desleal. São Paulo: Revista dos Tribunais, 1980.

SZTAJNBERG, D. Propriedade intelectual e reserva de mercado: algumas notas. p. 369-78. In: MARSHALL, C. C.; GOMES, J. M. M. (Coord.). Direito empresarial público. Rio de Janeiro: Lumen Júris, 2004. v. 2.

TAVARES, A. R. Direito constitucional econômico. São Paulo: Método, 2003.

TOLEDO, G. A. de. O direito constitucional econômico e sua eficácia. Rio de Janeiro: Renovar, 2004. 
